Research Report No. 40/2009

\title{
The Five Lessons I Learned through Clinical Education
}

Nadia Chiesa

Follow this and additional works at: http:/ / digitalcommons.osgoode.yorku.ca/clpe

\section{Recommended Citation}

Chiesa, Nadia, "The Five Lessons I Learned through Clinical Education" (2009). Comparative Research in Law \& Political Economy. Research Paper No. 40/2009.

http://digitalcommons.osgoode.yorku.ca/clpe/150 


\section{Comparative Research in Law \& Political Economy}

\section{CLPE RESEARCH PAPER 40/2009}

\section{Nadia Chiesa}

\section{The Five Lessons I learned through Clinical Education}

EDITORS: Peer Zumbansen (Osgoode Hall Law School, Toronto, Director, Comparative Research in Law and Political Economy, York University), John W. Cioffi (University of California at Riverside), Nassim Nasser (Osgoode Hall Law School, Toronto, Production Editor)

Also Available at http://www.germanlawjournal.com 



\section{German Law Journal}

The Five Lessons I Learned through Clinical Education

Nadia Chiesa

10 German Law Journal 615 (2009), available at:

http://www.germanlawjournal.com/article.php?id=1142

This article was originally published in Volume 10, Number 7 of the German Law Journal as part of the journal's $10^{\text {th }}$ anniversary symposium on "Transnationalizing Legal Education" edited by Nadia Chiesa, Adam de Luca, and Bernadette Maheandiran. 
CLPE Research Paper 40/2009

Vol. 05 No. 07 (2009)

Nadia Chiesa

\title{
The Five Lessons I Learned through Clinical Education
}

\begin{abstract}
Legal education has long been criticized for failing to prepare students for the realities of the practice of law. This article explores how clinical legal education programmes, offered at many Canadian law schools, may respond to this criticism and provide an alternative to traditional legal education. Through a reflection on the experience of working as a student at a community legal aid clinic, the author offers a student's perspective on the challenges and rewards of pursuing this type of legal education and discusses how clinical legal education may better equip law students for their future career.
\end{abstract}

Keywords: Legal Education, Clinical education

JEL classification: K10, K40

Nadia Chiesa

Nadia Chiesa is a JD candidate (2010) at Osgoode Hall Law School, Toronto, Ontario and the M anaging Student Editor of the German Law Journal. She worked at Osgoode's Community and L egal Aid Services Programme (CLASP) in 2008-2009.

Email: mailto:nadiachiesa@osgoode.yorku.ca 



\title{
SPECIAL ISSUE: TRANSNATIONALIZING LEgaL EdUCATION
}

\section{The Five Lessons I Learned Through Clinical Education}

\author{
By Nadia Chiesa*
}

In his 1935 indictment of legal education, Karl Llewellyn denounces the law schools of his time as factories pulling in immature, unprepared young men and, three years later, churning out young lawyers who are not significantly better prepared to deal with the realities of the legal profession. ${ }^{1}$ Llewellyn's critique touches upon every aspect of the North American legal education experience: the admission of students who lack the necessary critical research and writing skills, the rules-based "casebook" curriculum that ignores policy or practice questions and the release of graduates into the profession, without any follow-up on their experience that could be used to improve the education of the next generation of lawyers. In short, these graduates may have studied law, but they are not ready to practice law.

Writing almost 75 years ago, Llewellyn's critique can still be applied to contemporary legal education. This approach to learning, still so common in many law schools, is ingrained in future law students before our first day of law school as we cram for the dreaded LSAT admissions exams and struggle to distil a lifetime of experiences and expectations into the succinct statement of interest required for every law school application. Once accepted, we are immediately thrown into a large lecture hall where the professor will expound on property or torts or criminal law, rambling off long lists of cases and precedents, only to send us home to read hundreds of pages from our brick-like casebooks. We repeat this process for about three months, and then spend a frantic few weeks preparing the legendary "summaries" that we have heard will make or break us. Finally, we sit the final, three-hour, $100 \%$ exam and hope for the best. We will do this for three years, proudly accept our degrees in front of beaming family and friends and then realize that we are actually lawyers now. While this description may oversimplify the experience, it is an accurate representation. What would Llewellyn say if he saw that, more than seven decades, law school really has not changed very much?

Llewellyn offered a prescription for legal education which included, very briefly: looking to the demands on a practicing lawyer to inform what is taught to law students - and how it

\footnotetext{
* Nadia Chiesa is a JD candidate (2010) at Osgoode Hall Law School, Toronto, Ontario and the Managing Student Editor of the German Law Journal. She worked at Osgoode's Community and Legal Aid Services Programme (CLASP) in 2008-2009. Email: nadiachiesa@osgoode.yorku.ca

${ }^{1}$ On What Is Wrong With So-Called Legal Education, 35 Columbia LAW REVIEW 651-678 (1935).
} 
is taught; ${ }^{2}$ integrating social fact and policy with legal rules; ${ }^{3}$ and, ensuring students graduate with the critical and practical tools they need. ${ }^{4}$ Change depends, however, even more so on Llewellyn's "proposition that the health of any university, and more particularly of any law school, rests in departure from normality and deadly sanity. Freak persons and freak policies are needed; needed in very considerable measure. ${ }^{\prime 5}$ For Llewellyn, these freaks were those who were willing to challenge the status quo in order to affect change but change, it seems, would be a very long time coming since these freaks were few and far between. Rather than despairing over everything that has not changed in legal education since the 1930s, Llewellyn could take heart in knowing that while the freaks have not yet won, they have been waging the war on one of the most significant battlegrounds: clinical education.

Law schools across Canada offer clinical education programs, which, to varying degrees, allow students to put the skills they have learned in the classroom into practice in different "real world" settings, from storefront legal clinics to courthouse duty counsel to placements with private firms or NGOs. This article will focus on my experiences in clinical education, exploring how my work at a student-run poverty law clinic has subverted the traditional law school experience and, I argue, answered Llewellyn's call for change more than 70 years later by challenging mainstream legal education and, by extension, the mainstream legal profession.

Many of Llewellyn's critiques of legal education are being echoed in relation to contemporary legal education. In this article, I will explore these criticisms and discuss how clinical legal education has the potential to address and perhaps even remedy these concerns. Throughout, I will share reflections on how my personal experiences working at CLASP have shaped my time at law school and will, I believe, influence my future practice as a lawyer.

\section{A. CLASP}

CLASP is one of several clinical education programs offered by Osgoode Hall Law School. Dalhousie Law School in Halifax in the Canadian Maritimes claims to have the oldest clinical

\footnotetext{
${ }^{2}$ See, supra, note $1,667,668$.

${ }^{3}$ Llewellyn, supra note 1,669 .

${ }^{4}$ Ibid., at 673, 674.

${ }^{5}$ Ibid., at 651 .
} 
program, started in $1970,{ }^{6}$ but since 1969, CLASP has offered legal services to low-income people and communities in Toronto. The clinic is located within Osgoode Hall Law School and while clients come from across the city, a majority of clients come from the surrounding neighbourhood of Jane-Finch, which is one of the highest-density and poorest communities in Canada. Currently, CLASP provides representation in four areas: criminal law; immigration and refugee law; community support (represents clients living with mental health issues in housing matters, social assistance appeals and human rights complaints); and, youth and education. Potential clients must meet the financial eligibility requirements set by Legal Aid Ontario, which funds the clinic in part. Priority is given to clients who fall within the groups identified as most in need of assistance: those living in Jane-Finch, newcomers to Canada, women survivors of domestic violence, youth and individuals living with mental health differences.

Every year, 15 second- or third-year students are selected to participate in the 12-month program. Students are paid to work at CLASP full-time during the summer (May-August) and continue working there during the school year (September-April) for academic credit, while also taking courses. Supervised by three full-time lawyers, students work on all aspects of a client's case, including representing clients at criminal and small claims court as well as at a variety of administrative tribunals. Students gain a year of practical experience before they even graduate. In addition to traditional legal representation, students are involved in a variety of community outreach programs, facilitating legal education workshops, participating in grassroots community organizations, organizing law reform projects and more.

Criticism of traditional legal education is often tied to criticism of the traditional legal profession. In contrast to regnant lawyering ${ }^{7}$ is rebellious lawyering, a term coined by American lawyer Gerald Lopez. Where a regnant lawyer individualizes legal problems, ${ }^{8}$ a rebellious lawyer sees her clients as belonging to a larger community. ${ }^{9}$ Where a regnant lawyer sees a client's issue only in terms of legal issues and solutions, a rebellious lawyer considers the various societal forces and pressures in a client's life that may be contributing to or even causing the issue. Where a regnant lawyer relies only upon his or her own expertise, a rebellious lawyer seeks to empower the client.

\footnotetext{
${ }^{6}$ Rose Voyvodic \& Mary Medcalf, Advancing Social Justice Through an Interdisciplinary Approach to Clinical Legal Education: The Case of Legal Assistance of Windsor, 14 WASHINGTON UNIVERSITY JOURNAL OF LAW \& POLICY 101-132 (2004).

7 Paul R. Trembaly, Rebellious Lawyering, Regnant Lawyering, and Street-Level Bureaucracy, 43 HASTINGS LAW JOURNAL 947-970 (1991).

${ }^{8}$ Janet E. Mosher, Legal Education: Nemesis or Ally of Social Movements?, 35 OsGoOde HalL LAW Journal 613-635 (1997).

${ }^{9}$ Tremblay, supra, note 7.
} 
Just as rebellious lawyering challenges the traditional model of legal practice, clinical education programs like CLASP challenge the traditional model of legal education, pushing students to rebellious learning, in which they can develop a critical consciousness of the role and limits of law. These rebellious learners develop not only the strong analytical and advocacy skills that are required to practice any area of the law but they also develop a real understanding of the impact of the legal system on a section of society that is largely ignored. Bridging the gap between regnant and rebellious lawyering - and between regnant and rebellious learning at law school - has been one of the challenges I have grappled with during my time at CLASP and one that I am certain to be confronted with in the course of my career.

While it would be impossible to fully capture what I have learned from this experience, five important themes or lessons have emerged from my work with clients and in the community as well as from my discussions with colleagues.

\section{B. Lesson 1: You're a (student) lawyer - so what?}

In the classroom, the students listen to the professor and in practice, the clients listen to the lawyer; traditional legal education and practice depend on this expert-layperson relationship. Shin Imai, a professor at Osgoode Hall Law School, ${ }^{10}$ writes that law school teaches you how to be an instant authority. After all, we spend three years learning to synthesize lengthy cases into succinct ratios and apply those rules to facts to determine the likely outcome. Law plus facts - that is the equation that matters at law school - and we learn to cook the books to make the law work in favour of the facts of a particular case. As he says, we learn "to reconstruct events, to restate the law and to package a new reality. ${ }^{11}$ As law students, we learn that the lawyer provides the solution to the client. ${ }^{12}$

One of the hardest lessons I learned at CLASP was that this formula does not always work. With little background in employment law I happened to inherit a wrongful dismissal case at the time of joining CLASP. The client had been terminated from a menial, low-wage job without cause, without notice and without adequate termination pay. The facts of the case looked strong: a new Canadian working a low-paying job to make ends meet while she tried to start a new life for herself and her family in Canada faces racial discrimination and sexual harassment in the workplace, only to be fired. The case law also seemed to support our case. The previous student caseworker had prepared the client's statement of claim

\footnotetext{
${ }^{10}$ Shin Imai, A Counter-Pedagogy for Social Justice: Core Skills for Community-Based Lawyering, 9 CLINICAL LAW REVIEW 196 (2002).

${ }^{11}$ Ibid.

${ }^{12}$ Voyvodic \& Medcalf, supra note 6.
} 
and gone through a settlement conference, where the client turned down a settlement offer in favour of going to trial.

I took over the case a few months before the trial and I dutifully pored over the file, read up on employment law and developed a theory of the case. I soon realized that a recent ruling by the Supreme Court of Canada had drastically changed the claim and effectively barred us from making many of our claims. Working with my supervisor, we decided to advance those claims anyway, figuring that a judge at Small Claims Court might be more willing to overlook the law in favour of the sympathetic facts in the case. A few weeks before the trial, I started to meet with the client to prepare her. We went through the examination-in-chief as well as the cross-examination so she would be ready. I explained to her several times how the trial would work and what her role would be. I also stressed that we were not guaranteed success and that she would not necessarily be walking away with money in her pocket. She reassured me that she understood and that despite my warnings, she was confident the judge would believe her.

At the trial, the case went off the rails. The client, who had always been very forthcoming with the details of her experience, suddenly would not answer any questions related to her claim. She would not discuss the alleged harassment or discrimination. She could not remember dates or particular events that just days before, we had gone over in detail. She was, however, more than willing to shout abuse at the defendant's witness, her former manager. Even once she was off the stand, she continued to yell at the witness. In crossexamination, she changed her own story drastically, thereby undermining her entire claim. It was no surprise when the judge did not award the client the damages she had claimed. Outside the courtroom, the client approached me, visibly upset. She did not understand why she had been offered more at the settlement than she had been awarded at trial. But what really seemed to upset my client is that she could not understand why the judge would not let her tell her story, the way she wanted to tell it.

At the time of the trial, I had been working at CLASP for a little over four months. It is only recently, after almost a year at CLASP, that I have come to realize how I could have handled the situation differently. I had approached this case the way I had been taught, applying the rules to the fact to establish that my client should be awarded monetary compensation for the harm she had suffered. What I failed to consider at the time was that monetary compensation was not necessarily what my client ultimately wanted.

The expert-layperson relationship raises particular challenges for a student working in a legal clinic. First, clients often arrive at the clinic with mistaken beliefs about the law. During an intake interview, a potential client confided in me that since the police never found the "other" drugs in his car, we could use that to clear the possession charge he was currently facing. Another client was certain that his wife would be granted the necessary immigration papers because he had been granted his papers and their cases were very similar. In these cases, where I have to explain to a client that they are wrong about how 
the system works, I often ask myself: who am I to be telling the client he or she is wrong? As a law student, I have been very uncomfortable with taking on the role of expert. I may have taken an immigration law class, but my clients have actually had years of interactions with the Canadian immigration system. While I may be able to tell them what should happen in theory, they understand what actually happens to a claimant going through the system.

Another aspect of the expert-layperson relationship that has been difficult to overcome is the age difference that often exists with my clients. As a student in my twenties, many of my clients are twice my age. It can be disconcerting to have a client who is often the same age as my parents trust me with such an important life event as a hearing or trial. It becomes even more challenging in a situation where I have to confront an older client because she has repeatedly missed meetings or he has neglected to provide me with documents that are crucial to the case. In a society where we associate authority with age, the student caseworker-client relationship so often turns that dynamic on its head.

Finally, during my time at CLASP, I have become very aware of the power relationship that is created between lawyer and client. Just as some clients walk in with a definite idea about how law works, many others expect that I will have all the answers for them. Recently, when I was at the immigration detention centre where CLASP students provide legal information to detainees, I was explaining the detention system to two detainees when they asked me - point blank - whether they should apply for refugee status. An immigration officer had told them they could apply for refugee status if they feared returning to their country. I knew nothing about these detainees other than very basic details about how long they had been in Canada and how they had been picked up by immigration. After I explained what it meant to be a refugee, they again asked me whether they should claim refugee status. I told them that as a law student, I could not give legal advice and that they would have to make the decision on their own. It was a situation that made me acutely aware of the power - and responsibility - that we hold as lawyers (and even as law students).

I have experienced first-hand the different approaches to lawyering, whether labelled "regnant" and "rebellious" or "traditional" and "community-based", and the benefits or drawback of each during my time at CLASP. According to Janet Mosher, an Osgoode Professor and Associate Dean, clinical legal education can lead to a new vision of the legal profession. It can work to "shift from lawyering that truncates, to lawyering that empowers, [which] occurs when the emphasis of lawyering practices shifts from outcome to process; from getting to becoming; from instrumentalism to empowerment." ${ }^{\prime 13}$ This is a lesson that I hope to carry with me during the transition from school to practice and beyond.

\footnotetext{
${ }^{13}$ Mosher, supra note 8.
} 


\section{Lesson 2: Learning clinic or legal clinic?}

The approach to learning the law at CLASP has been vastly different to law school classes. In law school, we learn by reading, not by doing; we absorb "knowledge that" rather than developing "knowledge how". This approach to learning is then applied in practice. This application begins law school exams, which are usually based on fact-patterns that require to students to identify the issues and then apply the law to the facts provided and determine the likelihood of success for each party in the matter. Once students graduate and start dealing with clients, the same approach is used. Students are expected to transform their "knowledge that" into "knowledge how". The assumption is that a client arrives at a lawyer's office with a problem that is legal in nature and seen as "predictable, controllable and standardized." ${ }^{14}$ Since the possible solutions are also legal, the lawyer then applies the law to the facts.

The pedagogical structure of law school not only affects what we learn, but also what we do with our education. Law school still focuses, for the most part, on business and corporate law as well as litigation, with little discussion, at least in first year, of other options. Traditionalists would argue, of course, that it is necessary to learn the basics tort, criminal, contracts, property - first, however, this can create an alienating learning environment for students who may not have their sights set on large, traditional law firms. Further, the curriculum which focuses almost exclusively on substantive law and procedure can dissuade students from following a path in social justice, even when that is one of the motivations that first brought them to law school. ${ }^{15}$

Students participating in clinical legal education can pursue a commitment of social justice and develop "knowledge how" but during the course of this opportunity, will confront some of the ethical concerns associated with these types of programs.

Many of our clients arrive at CLASP as a last resort. They cannot afford a lawyer and cannot get a legal aid certificate, which entitles clients to free legal services. They retain CLASP precisely because they do not have a choice. While we provide free legal services, clients provide us with real-life case studies. In the most literal sense, we practice law on these clients. A question that has been raised several times this year during discussions with colleagues at CLASP is "Are we just learning off the backs of the poor?" and after a year at CLASP, this is still a question that we are asking ourselves.

\footnotetext{
${ }^{14}$ Julie Macfarlane, A Feminist Perspective on Experience-Based Learning and Curriculum Change, 26 OTTAWA LAW REVIEW 357 (1994).

${ }^{15}$ William P. Quigley, Letter to a Law Student Interested in Social Justice, 1 DEPAUL JOURNAL FOR SOCIAL JUSTICE 6-28 (2007).
} 
Constantly asking ourselves this question will not lead us to a definitive answer, but rather a critical awareness of the dichotomous nature of this work which will help us to recognize the power and privilege we have as lawyers and to challenge the hegemonic assumptions of our profession.

We must begin by considering our role as lawyers and what that can mean. Shelley Gavigan of Osgoode and former director of Osgoode's other legal clinic downtown, Parkdale Community Legal Services, has written about the "white knight" syndrome that can afflict lawyers working in social justice. There can be a tendency to believe that with law as our sword and shield, we can save the oppressed. This reflects the over-emphasis that is traditionally placed on the role and efficacy of law. Working at CLASP, this illusion was shattered for me very quickly. For example, Small Claims Court is often lauded as the solution to improving access to justice because claimants can self-represent and court fees are significantly reduced. This year, I spent too many hours trying to interpret the convoluted court rules, only to be told that I could not file a document because I had missed a small technicality. Each judge seems to apply his own interpretation of the rules, so there is no consistency between steps that must be taken throughout the life of a case. Finally, the court fees may be significantly reduced as compared to those in Superior Court, but for a client who makes less than minimum wage or lives on social assistance, having to pay a $\$ 100$ filing fee is nearly impossible. In law school, we discuss how to remove barriers and improve access to justice. In my experience at CLASP, as illustrated through this example of Small Claims Court, I learned how we often fail to even recognize the barriers that exist. If we cannot recognize the barriers, how can we move toward removing them and opening the justice system to all citizens? This was one of the hardest, but most valuable, lessons I learned in my time at CLASP and one that I would not have learned by sitting in a classroom.

What then is the alternative to the legal white knight? Well, the danger is that students can become mere tourists in a community that is new to them. ${ }^{16}$ At CLASP, the emphasis on community outreach work, such as getting involved with community groups and presenting legal education workshops, in addition to legal casework may help us avoid becoming tourists. We work with established community organizations and groups not as the "expert" coming in to fix the problem but as another member of the team, willing to put our skill set to use in the way that the community feels would help. While we offer a service to the community, we must learn to refrain from imposing a vision of how clients should use that service.

\footnotetext{
${ }^{16}$ Imai, supra note 10.
} 


\section{Lesson 3: The outsider looking in - or the insider looking out?}

Working at CLASP, I have become aware of the role that "social" plays in social justice. I was fortunate enough in my first year of law school to have a couple of teachers who introduced critical perspectives such as feminist and critical race theories into the course material, pushing us to analyse the social and political undercurrents in decisions. This is not, however, the norm in law school. "The tendency of law school to ignore political, economic, and social values and perpetuate has been blamed for helping to perpetuate idealized notions of fairness that fails to accord with the realities of poverty and discrimination."17 Even the mandatory first-year ethics class, where the prevailing theme is access to justice, fails to go beyond readily apparent financial reasons why so many Canadians cannot afford to access justice.

My year at CLASP, however, has enabled me to develop an awareness of the multidimensional social, political and economic factors which influence law and, more significantly, the lives of those people who are most frequently embroiled in the legal system. I have developed this awareness through my work with clients and the community, and through taking the time to reflect on and discuss these experiences with my colleagues. During our two-week training session last May, I attended a protest against temporary employment agencies in the Jane-Finch community with the other students from CLASP. My use of the word "attended" is intentional. That afternoon, I did not feel that my presence at the protest was at all helpful or supportive. I had no connection to the issue and, quite frankly, at that point, little connection to the community. I felt, to use Imai's words, like a tourist. Flash forward to February, when I participated in a march against police brutality in Jane-Finch, organized by members of the community after three separate incidents of youth being beaten by police. I was still highly aware of my status as an outsider at the event, no more so than when I was approaching people on the street and at the bus stop to collect signatures for an open letter to the local police department. The difference this time, however, was that through my work, I had developed a deeper understanding of the dynamics in the neighbourhood. Jane-Finch was no longer the gunsand-gangs war zone I read about on the front page of the newspaper; it was a community and a neighbourhood where many of my clients lived and worked and where we were involved. ${ }^{18}$

\footnotetext{
${ }^{17}$ Voyvodic \& Medcalf, supra note 6.

${ }^{18}$ For an account of a teacher's experiences in the Jane-Finch community, see PETER MCLAREN, CRIES FROM THE CORRIDOR (1980).
} 


\section{E. Lesson 4: Law is rational, not emotional - or is it?}

In law school, we learn to think rationally, not emotionally. In formal advocacy training, we are taught to replace "I feel" and "I believe" with "I submit". In torts class, we read about the reasonable person against whom standards are measured. People are even missing from the cases we read since the appellate cases taught in law school focus on judicial reasoning rather than the facts of the case. Julie Macfarlane describes this as "knowledge that", rather than "knowledge how" ${ }^{19}$ The curriculum and pedagogical styles are focused on getting knowledge, ${ }^{20}$ which is illustrated in the notoriously heavy reading loads in most courses. Both the form and substance of a legal education reflects an underlying rationalist model of knowledge that law can be "objective, certain and universal." ${ }^{21}$ The relationship between professor and students in the classroom is, largely, that of expert and novice; the professor imparts his knowledge to the student, who is the "theoretical spectator". ${ }^{22}$ That student must then, at the end of the term, apply that knowledge to a 100-percent exam.

While in traditional law classes, knowledge is conceived as a commodity which can be acquired, clinical education approaches knowledge as always evolving from experiences, both as we live through them and later as we reflect upon them. In sharp contrast, proponents of clinical education emphasize the contribution of personal experience and reflection in the learning process. Here, emotional and intellectual learning and development are interdependent. ${ }^{23}$ Learning is a continuous process, constantly changing and evolving based on new experiences. ${ }^{24}$ One of the skills student caseworkers learn at CLASP is to look beyond the obvious labels ('single mom', 'youth with a criminal record', 'drug addict') that may be applied to clients and see them as individuals. In the spirit of rebellious lawyering, we must maintain an awareness of the collective issues that our clients face but we must not jump to lump our client in with that group. In doing this, it is very difficult not to become emotionally involved in the case and when working in a legal clinic, "an intense level of emotional engagement is often unavoidable." ${ }^{25}$

My introduction to affective learning came rather late in my placement at CLASP. While I try to maintain an awareness of the social factors underlying a case, I also keep myself

\footnotetext{
${ }^{19}$ Macfarlane, supra, note 13.

${ }^{20}$ See, supra, note 17.

${ }^{21}$ Macfarlane, supra, note 13.

${ }^{22}$ Mosher, supra, note 8.

${ }^{23}$ Macfarlane, supra, note 13.

${ }^{24}$ See, supra, note 21.

${ }^{25}$ Imai, supra, note 10, 216.
} 
emotionally distanced from my clients and their cases. Since I have never been an outwardly emotional person, I would like to think that this is not a conscious effort to depersonalize my clients and adhere to a rationalist model of lawyering but rather a result of my personality. I do not feel that my emotional detachment has diminished the quality of my advocacy on behalf of clients although it has most likely affected the working relationships I have developed with clients.

In early spring, I took on a new case of a young mother who was facing deportation, which would separate her from her Canadian husband and her young children. Her efforts to regularize her status had been unsuccessful, in large part because she had been conned by paralegals. With no money, she had few - if any - options when she arrived at CLASP. For the first time, I became emotionally involved in a case and I am still in the process of reflecting on why this happened. The client's story was undeniably sad but working in CLASP's immigration division, many of my clients have equally heart-wrenching stories. The client had fallen through the cracks of the legal system but so too have the majority of CLASP's clients. The client had been ripped off by unscrupulous paralegals but I was representing another client in Small Claims Court in a very similar claim. In short, there was no reason why this particular client should have affected me in the way that she did.

\section{F. Lesson 5: Quick, get uncomfortable}

In his article "Letter to a Law Student Interested in Social Justice", Quigley advises that "the first step to any real educational or transformative experience [is] a willingness to go beyond your comfort zone and to risk being uncomfortable." ${ }^{26}$ Generally, I would argue that law students are, for the most part, used to being comfortable. We are comfortable in the sense that we have enjoyed some degree of privilege that gave us access to the opportunities that led to law school. We are also comfortable in the sense that we are used to having control over our environment, our experiences and our interactions. Law school is a largely solitary experience, where competition is prized over collaboration and students are trained to work in an individualistic and adversarial legal system. ${ }^{27}$ In their article about the University of Windsor's legal aid clinic, Voyvodic and Medcalf suggest that the "subject-matter of clinical legal education (i.e., poverty law), its unstructured nature and its closeness to inter-personal dynamics is unsettling to mainstream faculty accultured to 'isolationist' mode of behaviour within legal education." ${ }^{28}$ For Quigley, social justice lawyers must learn to be uncomfortable because "those who practice social justice law are

\footnotetext{
${ }^{26}$ Quigley, supra, note $14,15$.

${ }^{27}$ Voyvodic \& Medcalf, supra, note 6.

${ }^{28}$ See, supra, note $25,106$.
} 
essentially swimming upstream while others are on their way down." ${ }^{29}$ I would add that for a law student working in a legal clinic, the work that we do, and the places where we do that work, also forces us to go beyond our comfort zone.

Throughout my time at CLASP, I have experienced two distinct types of discomfort. The first, the sense of anxiety I have experienced when appearing in court or presenting on panels, can be attributed to my lack of experience and yet is still within my "comfort zone" to the extent that I retain some degree of control over the situation. The second is the kind of discomfort that Quigley described and has truly pushed me beyond my comfort zone, leading, I believe, to a real educational experience.

Two of my most uncomfortable experiences have occurred in the course of my work on a law reform campaign around the disclosure of mental health police records, a practice which violates the privacy of personal health information and leads to discrimination on the basis of a disability. Ironically, this is one of the projects at CLASP about which I am most passionate. Throughout this campaign, we have been working with members of the mental health consumer/survivor community. In July, we participated in Mad Pride, an event organized by various consumer/survivor groups that brings together artists and activists. We tabled our petition at the event, explaining the issue to attendees and gathering signatures. Later in the year, working on the same campaign, I attended a meeting of the Centre for Addiction and Mental Health's Empowerment Council organized in response to a discriminatory ad put out by a powerful union. At both of these events, I quickly realized just how uncomfortable I felt. In the moment, I had trouble identifying the reason for my discomfort. Looking back, I realize that I felt encumbered by my status as an outsider (similar to the experience I discussed in Lesson 3 ) and worse, I felt like a voyeur. I am very involved in this law reform campaign but my interest is more academic than personal. The consumer/survivor initiatives are (and this is a gross oversimplification) about taking back the labels, the experience and the power of mental illness from outsiders, including the medical and legal communities. Explaining the issue of mental health police records to Mad Pride participants and attending the Empowerment Council meeting, I felt as thought I had no right to be there.

I am still struggling with my role and my relationship to this particular project. I recognize what I can bring to this issue but I still am also very conscious of my status as an outsider, especially when I speak about this issue at conferences or public meetings. Through this experience of continuous self-inquiry and reflection, I have come to understand more fully the learning process in which I have engaged during my time at CLASP and which I can continue throughout my career.

\footnotetext{
${ }^{29}$ Quigley, supra, note $14,10$.
} 


\section{G. Llewellyn's freaks: Still fighting after 75 years}

While legal education may not have changed dramatically since Llewellyn's time, law students do have the opportunity to choose clinical education programs like CLASP and challenge the educational (and later professional) status quo. As I look toward the end of law school and the beginning of my career, I do not know where my career will take me but I do know that I will carry with me the lessons I learned at CLASP and proudly count myself among Llewellyn's freaks. 
